\title{
Five Years Experience in Upper South Vietnam with Dialide, and Comparison with DDSO
}

\author{
N. P. BUU-HOI, * LE-KHAC-QUYEN, $\dagger$ and N. D. XUONG \\ Dr Buu-Hoi of Vietnam is now resident at 26 rue d'Ulm, Fendtion Curie, Paris (Ve), France
}

4, 4'-Diethoxythiocarbanilide (Dialide), a tuberculostatic agent discovered by R. L. Mayer, was introduced in Vietnam for the chemotherapy of leprosy in 1953 - the first thiourea to be used anywhere for this purpose - and rapidly proved successful in all forms of the disease, either alone, or in combination with drugs belonging to other families $\left({ }^{1},{ }^{2},{ }^{3}\right)$. The rationale for proposing this compound for clinical trials was based on (a) the high tuberculostatic activity of many thiocarbanilides (or $\mathrm{NN}^{\prime}$-diarylthioureas), including this very one $\left({ }^{4},{ }^{5}\right)$, coupled with some growth-inhibiting effects towards certain pathogenic fungi (an association of properties that is thought to be significant for the selection of potential antileprosy drugs $\left({ }^{6}\right)$; (b) the compound's exceedingly low toxicity, both acute and chronic (its $\mathrm{LD}^{50}$ per os, determined in rats, is well over $5 \mathrm{~g}$. $/ \mathrm{kg}$.); (c) the very low cost of its preparation, a particularly attractive feature for its use in under-developed countries; (d) and last but not least, its lack of tendency to induce or maintain reactional states in the patients. Since these initial observations, other thiocarbanilides have been introduced in leprosy therapy with considerable success, notably CibaI 906 (a compound with an amine function) by Davey $\left({ }^{7}\right)$ and others, and Isoxyl (a higher homologue of Dialide) by our group ( ${ }^{8}$ ) and by Griffiths $\left({ }^{9}\right)$. Dialide itself has been successfully used in Japan $\left(^{10}\right)$; in the Soviet Union it has been advocated as a subsidiary chemotherapeu- tic agent for tuberculosis, and reports have appeared in the recent Russian literature on its good effects in all forms of leprosy $\left.{ }^{(11}\right)$.

During the past 12 years, Dialide has been one of the major drugs used throughout South Vietnam for both hospitalised and ambulatory patients, and the experience thus acquired in a very great number of cases, some following a regular pattern of treatment, others undergoing therapy erratically (as is so often observed in this part of the world), allows some conclusions as to the influence of the drug, and perhaps to its mode of action.

In view of certain favourable local conditions (existence of close-knit communities and of a dedicated medical and paramedical staff) the upper regions of South Vietnam have provided the most reliable ground for such an evaluation. This report will therefore deal mainly with the results obtained in that area, above all in the province of Thua Thien. This coastal province, of which Hué is the capital, lies some $80 \mathrm{~km}$. south of the $\mathrm{I}^{7}$ th parallel (the demarcation line between North and South Vietnam), and has a population of some 400,00o. As the incidence of leprosy estimated for the lowlands + is 3.5 per thousand, this would give an approximate figure of I, 400 patients for that province. During the five-year period of our campaign, we registered 700 patients. It is worth mention that the execution of our project was fraught with difficulties, due to the conditions of war prevailing.
* Former Adviser to the Ministry of Health (Government of Vietnam) and Member of the Panel of Experts (Leprosy), W.H.O., present address: 26 Rue d'Ulm, Paris (V), France.

$\uparrow$ Former Dean of the Faculty of Medicine and Director of the Central Hospital, Hué.

${ }_{+}^{+}$South Vietnam is divided into lowlands, inhabited by people of Vietnamese stock, and highlands, where the main population is made up of tribes of different ethnic origin; the incidence of leprosy among the latter is considerably higher (estimated at at least 7 per cent). Another difference is the frequency of the lepromatous form in the lowlands, in contrast with the predominance of the tuberculostatic form in the highlands (12).

Five Years Experience with Dialide $\mathrm{I}_{5}$ 


\section{Organisation of Campaign}

The Leprosy Wing of the Central Hospital of Hué contained 65 beds and an out-patient department. Those of our patients who were in reactional states, the severe lepromatous cases, and some patients with extensive and painful perforating plantar ulcers, were hospitalised; the rest attended as out-patients. Laboratory tests included monthly nasal smears and skin biopsies; once smears and biopsies had remained negative for three consecutive months, the hospitalised patients able to walk were discharged and became out-patients. Among the nursing staff were four former patients whose 'negativation' dated from at least four years and who had undergone training both in the ward, and as outside visitors, where, in the outlying villages, they identified the sick and were, by their personal example, the most apt for encouraging the newly-detected cases to join in the chemotherapy project.

\section{Protocol of Chemotherapy}

Dialide, prepared in almost quantitative yield by the reaction of carbon disulphide on phenetidine (an inexpensive chemical intermediate widely used in the pharmaceutical and dyestuff industries) and recrystallised from ethanol, is a white crystalline powder melting at $\operatorname{circa}$ I $76^{\circ} \mathrm{C}$, odourless, and with a bitter taste; it is insoluble in water and barely soluble in vegetable oils, and the most suitable galenic form is therefore tablets. The tablets, each containing $250 \mathrm{mg}$., were made at the pharmaceutical section of the Ministry of Health in Saigon, and put at our disposal. During the entire 5-year period, the patients received from $500 \mathrm{mg}$. to $75^{\circ} \mathrm{mg}$. per day, without interruption whatsoever.

In order to assess the possible beneficial influence of a combination of drugs, a certain number of patients were given, along with the Dialide, $50 \mathrm{mg}$. of DDSO (4, 4'-diaminodiphenylsulphoxide) daily, six days per week (the earlier-advocated dose of I oo $\mathrm{mg}$. (13) was reduced by half when several separate chemotherapeutic trials with DDSO alone had demonstrated the adequacy of the lower dosage and the lesser occurrence of side-effects $\left({ }^{\mathbf{1 4}}\right)$, except when a reaction episode set in, whereupon the patient was put back on Dialide alone. For a study of comparative long-term efficacies of Dialide and DDSO, a third, small group of patients was treated with DDSO alone; here again, administration of the drug was interrupted during reactional periods.

Adjuvant therapy in all cases comprised vitamins of the B complex.

\section{Tolerance of Drugs}

Daily administration of Dialide, even prolonged over five years as in the conditions of our trial, led to no side-effects nor signs of intolerance, and it was possible to administer it throughout reactional onsets without any exacerbation of the course of the reaction; in no case was there evidence that administration of Dialide had directly induced erythema nodosum leprosum. DDSO, in the lower dosage of $300 \mathrm{mg}$. per week, and given to patients on an adequate liquid intake, did not produce the transient renal lesions reported by Browne et al. $\left(^{15}\right)$ and which we ourselves observed in some cases receiving the higher $600 \mathrm{mg}$./week dosage. On the other hand, reactional episodes induced by administration of DDSO (alone or in combination) were frequent.

\section{Results}

Out of the 700 patients registered, we retained only 5 I 9 , the remaining i 8 I having been found to take their drug irregularly, or having been lost from sight. The breakdown of these 5 I 9 is as follows:

\begin{tabular}{|c|c|c|c|}
\hline \multirow{4}{*}{$\begin{array}{l}\text { Form } \\
\mathrm{L} \\
\mathrm{T}\end{array}$} & \multicolumn{3}{|c|}{$D R U G$} \\
\hline & Dialide & Dialide $+D D S O$ & DDSO alone \\
\hline & 248 & 70 & 24 \\
\hline & 68 & 71 & $3^{8}$ \\
\hline Totai & 316 & I 4 I & 62 \\
\hline
\end{tabular}

Patients classified for practical purposes as 'apparently cured' were those whose routine laboratory tests showed persistent bacterial negativization of nasal smears and constant bacteriological improvement in serial skinbiopsies, together with disappearance of the evolutive skin lesions and of the tenderness and swelling of the nerves; these patients were then returned to normal life, whilst being maintained on therapy. In the light of these norms, results were as follows: 


\begin{tabular}{lcccccc}
\hline \multirow{2}{*}{ Form } & \multicolumn{2}{c}{ Dialide } & \multicolumn{2}{c}{ Dialide + DDSO } & \multicolumn{2}{c}{ DDSO alone } \\
& $\begin{array}{c}\text { Number of } \\
\text { patients }\end{array}$ & $\begin{array}{c}\text { Apparently } \\
\text { cured }\end{array}$ & $\begin{array}{c}\text { Number of } \\
\text { patients }\end{array}$ & $\begin{array}{c}\text { Apparently } \\
\text { cured }\end{array}$ & $\begin{array}{c}\text { Number of } \\
\text { patients }\end{array}$ & $\begin{array}{c}\text { Apparcnlly } \\
\text { cured }\end{array}$ \\
\hline $\mathrm{L}$ & 248 & $\mathrm{I0} 6(42 \cdot 7 \%)$ & $7 \mathrm{O}$ & $29(4 \mathrm{I} \cdot 4 \%)$ & 24 & $\mathrm{I} 2(50 \%)$ \\
$\mathrm{T}$ & 68 & $26(38 \cdot 2 \%)$ & $7 \mathrm{I}$ & $39(54 \cdot 9 \%)$ & 38 & $\mathrm{I} 7(44 \cdot 7 \%)$ \\
\hline TotAL & $3 \mathrm{I} 6$ & $\mathrm{I} 32(4 \mathrm{I} \cdot 8 \%)$ & $\mathrm{I} 4 \mathrm{I}$ & $68(48 \cdot 2 \%)$ & 62 & $29(46 \cdot 7 \%)$ \\
\hline
\end{tabular}

From the above figures, it appears at first glance that Dialide is only slightly less effective than either the combination Dialide + DDSO, or DDSO alone (which latter is at least as active as diaminodiphenylsulphone $\left.\left({ }^{16}\right)\right)$. If this were indeed the case, then Dialide would hold a distinct lead over DDSO and the sulphones, being, unlike them, free from side-effects. Unfortunately, however, several of the patients on Dialide who had been 'negativized' and who were then switched to DDSO, developed reactional bouts, with bacteriological and clinical reactivation of the disease, and had to be put back on Dialide alone. This phenomenon was so regular an occurrence that patients kept on Dialide refused to be switched to another drug 'for fear of a relapse'. It is therefore probable that Dialide acts, in leprosy, less as a bactericidal than as a bacteriostatic agent, leaving in the body of the apparently cured patient, foci of residual infection which, under the eff ect of a reaction-inducing drug, can temporarily flare up. But so long as patients are kept free from such a 'therapeutic' triggering off, and are not attended by any breakdown in health, Dialide, in adequate dose levels, is able to maintain them in a state of 'apparent cure', seemingly for an indefinite period.

\section{A Limited Trial in the Highlands}

Since it is known that response to therapy tends to vary with the genetic stock of individuals, it was deemed of interest to investigate the effects of Dialide in leprosy among people of the highland tribes. A limited study, started in $195^{6}$, was carried out in the Leprosy Settlement of Ea-Ana, near the town of Ban-Me-Thuot, some $400 \mathrm{~km}$. north of Saigon. Thirty-four patients in this area were treated with Dialide, in a lower dosage of I oo mg. per day, six days per week. Because of the conditions of war, records were obtainable for only 2 I among them. Out of these 2 I, I 2 were lepromatous cases, six tuberculoid, two dimorphous, and one indeterminate; eight patients were known to be reaction-prone.

Nine patients showed, after three years' Dialide therapy, the same type of improvement as those in the lowlands. In two tuberculoid patients previously treated during four years with sulphone with little effect, regression of the macules and anaesthesia was spectacular; in two other patients (one dimorphous, one lepromatous, and both reaction-prone), bacteriological negativation was achieved in under two years, with recession of the skin lesions and anaesthesia.

For comparison, a group of eight patients was placed on DDSO, in a dose of first $50 \mathrm{mg}$., then I oo mg. per day, six days per week. The following Table shows the results:

\begin{tabular}{|c|c|c|c|}
\hline Form & Previous Therapy & Reactional Episodes & Bacterial Index and Comments \\
\hline $\mathrm{L}$ & New patient & I & $\begin{array}{l}\text { Bacterial index from }++ \text { to }+ \text { after } 39 \text { months; } \\
\text { I psychotic episode. }\end{array}$ \\
\hline $\mathrm{L}$ & Dialide & Io in 3 years & $\begin{array}{l}\text { Negativized after } 4 \text { years; anaesthesia mildly } \\
\text { improved. }\end{array}$ \\
\hline $\mathrm{L}$ & New patient & $\mathbf{I}$ & $\begin{array}{l}\text { Negativized after } 4 \text { I months; anaesthesia almost } \\
\text { completely disappeared. }\end{array}$ \\
\hline $\mathrm{L}$ & New patient & nil & Negativized after 3 years. \\
\hline $\mathrm{L}$ & New patient & 3 moderately severe & Negativized after 21 months. \\
\hline Dimorph. & DDS (anaemia) & nil & $\begin{array}{l}\text { Haemoglobin level improved; negativized after io } \\
\text { months; anaesthesia decreasing. }\end{array}$ \\
\hline $\mathrm{T}$ & DDS & nil & $\begin{array}{l}\text { Resolution of skin lesions; anaesthesia and bacilli } \\
\text { persisting after } 2 \text { years. }\end{array}$ \\
\hline $\mathrm{T}$ & DDS & nil & $\begin{array}{l}\text { Skin lesions and anaesthesia improved after } 16 \\
\text { months; bacteria still present. }\end{array}$ \\
\hline
\end{tabular}




\section{CONGLUSI ONS}

Insofar as five years' experience in Upper South Vietnam allows conclusions to be drawn, it can be said that Dialide, in adequate dosage, is a highly active therapeutic agent in both lepromatous and tuberculoid leprosy, free from sideeffects, and can be used throughout reactional episodes; the 'apparent cures' achieved are however less stable than those effected with the considerably more toxic DDSO, or with the combination Dialide + DDSO.

\section{A CKNOW LEDGEM E N T}

We thank the Minister of Health at the time, the Medical Staff of the American Leprosy Missions in Ea-Ana, and Dr Ton-That-Niem (Ban-Me-Thuot), for help in this study.

\section{RE FERENCES}

I N. P. BUU-hoi, N. B. Khuyen, and N. D. XuOng, Bull. Acad. Nat. Méd., r 955, r39, 275.

2 N. P. BUU-Hol, N. B. KHUYen, and N. D. XUONG, ibid., I $957, \mathbf{1 4 1}, 204$.
3 L. K. QUYEN, N. P. BUU-hö̈, and N. D. XUONG, ibid., I 960, r44, 535 .

4 R. L. MAYer, P. C. eisman, and E. A. KONOPKA, Proc. Soc. Exper. Biol. Med., I 953, 82, 769 .

5 N. P. BUU-Hoï, and N. D. xuOnG, C. R. Acad. Sci., I953, 237, 498.

6 N. P. BUU-Hoï, Internat. J. Leprosy, I 954, 22, I 6.

7 T. F. DAVEy and G. CURRIE, Lep. Rev., I 956, 27, 94; I $958,29,25$.

8 N. P. BUU-HOÏ, T. V. BANG, T. T. KIM MONG-DON, and N. D. XUONG, Chemotherapia, ig61, 2, I 22.

9 P. G. GRIFFITHS, Lep. Rev., I 965, 36, 23.

IO Y. HAYASHI, Transact. VIIth Internat. Congress Leprology, Tokyo, November I 958, p. 249.

I I V. K. LOGINOV, A. M. LETICHEVSKAYA, R. AKSANOVA, and G. A. KHRICOV, Lep. Rev., I 963, 34, 2 I 2.

I 2 P. HARTER and T. V. BANG, Internat. J. Leprosy, I96I, 29, 265 .

I 3 See ref. (I); also P. LAViron, L. LAURET, P. KERBASTARD, and c. Jardin, Bull. Acad. Nat. Méd., i 957, 141, I95; T. F. DAVEy, A. M. Kissaun, and G. moneta, Lep. Rev., I $957, \mathbf{2 8}, 5$ I.

i 4 Cf. A. BASSET, D. SicARd, i. FAye, and m. Basset, Bull. Soc. Méd. Afrique Noire, I964 (in press.)

I 5 S. G. BRoWNe and T. F. DAVEy, Lep. Rev., I96 I, 32, I94; s. G. BROWNE, Transact. VIIIth Internat. Congress Leprology, Rio de Janeiro, September I 963 (in press.)

i 6 T. F. DAvey, Transact. VIIth Internat. Congress Leprology, Tokyo, November I 958, p. $25^{2}$. 